Community gardening and governance over urban nature in New Orleans's Lower Ninth Ward

Catarina Passidomo, The University of Mississippi

Department of Sociology and Anthropology

Center for the Study of Southern Culture

112 Barnard Observatory

The University of Mississippi

University, MS 38677

passidomo@olemiss.edu 


\section{Community gardening and governance over urban nature in New Orleans's Lower Ninth Ward}

Abstract: Lefebvre's right to the city (RTTC) framework argues for a renewed politics of inhabitance in cities, which enfranchises urban residents to imagine and create urban space to meet their needs. Another theoretical framework, Urban Political Ecology (UPE) works to "untangle the interconnected economic, political, social, and ecological processes that go together to form highly uneven and deeply unjust urban landscapes" (Swyngedouw and Heynen 2003). In this paper, I draw connections between the RTTC framework and literature in Urban Political Ecology (UPE) to consider how their intersection can inform analysis of grassroots urban agriculture initiatives in the Lower Ninth Ward Neighborhood of New Orleans. I argue that community efforts to transform vacant lots into productive gardens and food forests constitute a specific form of claims on the right to the city, and on the right to alter and improve urban ecology. These claims play out at the scale of the neighborhood, rather than that of the city, and are manifested within specific urban sites managed by residents of a particular neighborhood. I characterize specific, neighborhood-scale urban greening efforts as "political moments" (Becher, 2012), which, despite their locational and topical specificity, offer profound potential for broader urban social change.

Keywords: Right to the City; Urban Political Ecology; Urban Agriculture; Urban Food System; New Orleans; Political Moments

\section{Introduction}

In February of 2013, the Lower Ninth Ward Food Access Coalition (LNWFAC), a grassroots, neighborhood-based organization, released a report and action plan for increasing access to what they deemed healthy and affordable food within the Lower Ninth Ward neighborhood of New Orleans, which has no grocery stores and very limited access to fresh foods. The release of the “action plan" marked the culmination of ten months' concerted effort towards articulating a plan of action that would both acknowledge and strategically endeavor to overcome the structural barriers to fresh food access within that neighborhood. Central to the plan were urban greening and urban agriculture initiatives, which would serve not only to address the food access problem, but also to immerse young people in community-shared green space. The efforts of the LNWFAC and affiliated community members are notable because of their endemic nature; while the group strategically mobilized outside resources and opportunities, they consistently demanded that efforts be governed and articulated by and for residents of the Lower Ninth Ward. 
By claiming their right, as citizens of a particular neighborhood, to determine the form, function, utility, and accessibility of neighborhood amenities — and, in fact, to demand equitable access to amenities deemed basic and fundamental for the healthy functioning of a neighborhood and its inhabitants - residents of the Lower Ninth Ward demonstrate claims on the right to the city as the right to inhabit and thrive within vital urban space.

Public green space and fresh food were among the "basic amenities" to which Lower Ninth Ward residents demanded access and control. Therefore, this particular manifestation of the right to the city is fruitfully analyzed here under the broader theoretical framework of urban political ecology (UPE). Drawing from eco-Marxist, eco-feminist and eco-anarchist perspectives, UPE links specific analyses of urban environmental problems- from poor air and water quality in inner-city neighborhoods to a lack of access to grocery stores- to larger socioecological solutions, such as policy changes that prohibit waste dumping or incentivize food markets to locate in poor urban neighborhoods (Keil 2003, p.724). UPE posits that urban environments are socially constructed spaces that can be interpreted as multi-dimensional physical manifestations of political will and structure, of community culture and identity, and of societal relationships with local "nature" (Keil 2003). Additionally, UPE is centrally concerned with contextualizing urban formations, and focuses primarily on the processes and practices that produce uneven and "spatially differentiated environments" (Braun 2005, p. 644), making it a particularly useful framework for investigating the discourses and contexts that shape food and land use activism in urban contexts.

This paper addresses a call within this journal for increased attention to issues of governance and power within urban forestry and green space ecologies (Bentsen, et al 2010). In so doing, it draws on existing research published in Urban Forestry and Urban Greening that 
focuses on the motivations and benefits of community gardens (Guitart, et al 2012); the challenges for urban green space planning (Haaland, et al 2015); the development of complementary frameworks for integrating governance into urban ecological systems (Kattel et al, 2013; Lawrence et al, 2013); and the transformative potential of food gleaning and cultivation for enhancing green space stewardship (McLain et al, 2012). These studies reveal a consistent and concerted interest in the role of local citizens for shaping and managing urban green space, but there is insufficient attention to how governance over that space actually happens, and what implications grassroots governance may have for both social and ecological processes at the neighborhood scale.

\section{Research Context}

Post-Katrina New Orleans provides a raw and unique setting for examining questions of power and governance over socio-nature. In August of 2005, a category 5 hurricane wrecked the coastal areas and towns of southern Louisiana and Mississippi, displacing more than a million people, causing at least 1,833 deaths, and incurring over \$108 billion (2005 USD) in damages (GNOCDC, 2012; Knabb et al 2005; NOAA, 2011). Despite the undeniable power of Hurricane

Katrina as a natural disaster, many argue that the extraordinary loss of life and property could have been much less severe, particularly in the city of New Orleans; a dilapidating levee system (long known to be inadequate if confronted by a category 4 or larger storm), government inaction leading up to and immediately following the storm, and a desire to preserve the historic and profitable French Quarter exacerbated the damage and destruction of the poorest neighborhoods of New Orleans (Dyson, 2006). In the days and weeks following the storm, public news stations around the United States and world broadcast images of unmoored homes, whole neighborhoods drowning under ten or more feet of water, people stranded on rooftops with nothing to eat or 
drink, and the floating corpses of those who could not escape the surge of Lake Ponchartrain. That most of these images captured people of color unsettled the notion that Katrina was a "natural" disaster; on the contrary, the sheer visibility of the violence and death absorbed primarily by poor people of color following the storm has made Katrina a "touchstone for public debates about the relationship between class, race, capitalism, the state and environment in America" (Bakker, 2005:795). Katrina did not cause urban racial and class disparity; it merely capitalized on it and rendered it visible.

Now, a decade after the storm, it is useful to reflect on what Katrina has meant for the urban fabric of New Orleans, and on the ways in which Katrina's aftermath exposed the fragility of the false dichotomy between nature and society. The years since Katrina have witnessed a demographic shift in the direction of whiteness and wealth, and an array of efforts to rebuild or reimagine the city, including initiatives to address food insecurity among low-income residents. Many scholars and activists have remarked on the tendency of rebuilding efforts to privilege exogenous ideologies and the interests of capital while disregarding the substantive needs and desires of those residents who have returned home (Hartman and Squires, 2006; Luft, 2008; Klein, 2007; Dyson, 2006; Harvey et al, 2015; Passidomo 2013.). Rather than reiterate their arguments, I pursue a different trajectory in this paper. Using the Lower Ninth Ward neighborhood of New Orleans as a case study, I explore the applicability and transformative capacity of Henri Lefebvre's concept of the right to the city (RTTC) for addressing specific grievances: a lack of fresh food access and a desire for resident-directed governance of public green space. I share stories and observations from a grassroots initiative led by residents of the Lower Ninth Ward to challenge both the systemic and specific circumstances that have circumscribed their access to fresh food, and demonstrate that this activism challenges dominant 
structures of governance over urban nature. In keeping with this issue's concern with power and governance, I situate the LNWFAC's struggle within the RTTC and Urban Political Ecology (UPE) frameworks to address the following questions: How do struggles over governance of urban space reflect a (re)distribution of power within urban socio-ecological systems? How does local knowledge function within these systems, which tend to privilege exogenous knowledge and "expert" ideologies? How can a neighborhood-scale struggle for fresh food access mobilize residents towards broader and deeper claims of self-determination and governance over urban nature? While this study approaches these questions through examination of a particular case, it offers insight into the transformative potential of local governance, and, specifically, to the neighborhood scale as a meaningful site for citizens to engage with questions of and control over urban green space.

To contextualize these questions, I begin with a brief description of the UPE framework, followed by theoretical engagement of Lefebvre's formulation on the Right to the City. I consider arguments that the RTTC concept is either too narrowly (Harvey, 2008: 38) or too broadly (Leontidou, 2010; Purcell, 2003; de Souza, 2012) applied, and focus on those elements of RTTC that are most salient to my investigation of urban green space governance in a particular neighborhood in New Orleans. Despite its highly theoretical nature, I argue that RTTC has broad applicability "in the real world" when paired with insights from Urban Political Ecology. The UPE framework grounds RTTC discourse within a particular socio-natural context, by calling for small-scale, grassroots governance over urban green space.

Next, I offer an ethnographic portrait of post-Katrina New Orleans, the Lower Ninth Ward Food Access Coalition (LNWFAC), and the latter's discursive and activist efforts to generate a community-controlled food system. Finally, I utilize an urban political ecology 
framework to link themes from the RTTC to the rights claims of the LNWFAC, and demonstrate the transformative potential of what Becher (2012: 203) describes as "political moments": the “intentionally temporary, grassroots organizing around small-scale, specific claims." I conclude by arguing that one emancipatory vision for the city starts from neighborhood efforts to radically incorporate the human needs for food and self-determination, to challenge corporate domination of the food system, and to collaboratively create useable urban space. One pertinent manifestation of this activism has been renewed access to and control over neighborhood green space, which in turn facilitates deepened community engagement, intergenerational interaction, and enhanced nature-literacy among the youth.

\section{Theoretical Framework}

This section engages with theoretical approaches to urban inhabitance and governance found in literature on urban political ecology (UPE) and the right to the city (RTTC). These literatures share a common interest in democratic decision-making, an intention to struggle, and a commitment among urban residents to determine the form and function of urban space. Taken together, they provide a useful framework for considering the case study that follows, and for exploring broader possibilities for local governance over urban nature.

\section{Urban Political Ecology: Power and governance in socio-natural systems}

UPE has been a useful guiding framework for conceptualizing urban environmental justice initiatives, because it accounts for some of the structural forces that generate and perpetuate unequal exposure to environmental "bads" (Bullard 1983; Bickerstaff et al. 2009), as well as disproportionate access to environmental "goods" (Heynen el al. 2006). For example, Nik Heynen utilizes a UPE framework to illuminate and analyze the social justice implications of 
urban hunger (Heynen 2006a), as well as how a spatially inequitable distribution of urban trees could reveal powerful racial and economic disparities in access to urban nature (Heynen 2006b). A similar application of the UPE framework to urban food movement discourses and activities can inform the multi-scalar connections amongst race, food, governance, and urban nature (McClintock 2010). As Domene and Sauri (2007) argue, "the kinds of landscapes we create are linked to wider issues of urban development, urban sustainability, and the social preferences of certain urban natures over others...neither socio-environmental changes nor environmental planning are socially or ecologically neutral" (p.288). Thus, urban landscapes can be read as manifestations of political and social relations that govern the right to the city, and the right of access to productive natural spaces. Rather than depicting urban green space as inherently "good," then, UPE can help to expose and critically examine the systems of governance and valuation that characterize particular manifestations of urban nature (c.f. Bentsen, et al, 2010).

For example, in the case of post-Katrina New Orleans, local officials and the power elite promoted an effort to transform low-lying demolished neighborhoods into green space after the waters receded; this initiative became known as the infamous "green dot plan," because areas marked as future green space (i.e., no rebuilding) were indicated as green dots on city planning maps and other documents ("Plan shrinks city footprint" 2005). The green dots corresponded with neighborhoods whose residents were primarily low-income people of color. In response to the notion that these were neighborhoods not worth saving, residents of many of the hardest-hit neighborhoods organized against the "green dot" green space plan by rebuilding into thriving communities ("Many areas marked for green space after Katrina have rebounded," 2010). This serves as a powerful demonstration that more green space is not always a good thing if it means restricting the agency and livelihoods of urban residents. UPE's specific concern with 
governance and power enables honest renderings of the complex interactions among urban residents, urban nature, and the powers that be. Henri Lefebvre's right to the city framework elaborates on and grounds discussions of urban residents' governance of the natural and built environments that surround them.

\section{Theorizing the Right to the City}

Originally formulated as a response to the increasing intrusion of exogenous capital and power into urban space, Henri Lefebvre's (1996) "right to the city" framework argues for citizen governance over that space. Lefebvre calls for a radical transformation of urban space that would "modify, concretize, and make more practical the rights of the citizen as an urban dweller and user of multiple services" (1996: 34). According to this radical formulation, urban inhabitants ("citadins") have both an entitlement and a responsibility to participate in the creation and governance of the city or neighborhood in which they reside. Because, according to Lefebvre, contemporary urban dwellers have been structurally and systematically denied the capacity to govern urban space, he calls for a grassroots appropriation of that space and the right of citadins to "physically access, occupy, and use" urban space "so that it meets the needs of inhabitants" (Purcell 2002: 103).

The RTTC framework thus renders the space of the city and the nature of urban citizenship as co-constitutive. David Harvey argues, "The right to the city is far more than the individual liberty to access urban resources: it is a right to change ourselves by changing the city" (Harvey, 2008: 23). Because enactment of the RTTC requires some degree of community engagement and a deepening of "the social" within cities-effectively generating a new, postcapitalist mode of production (Trauger and Passidomo 2012) - it is also a right to change the city by changing ourselves. Smith and McQuarrie (2012: 3) emphasize this potential by engaging the 
changing nature of urban citizenship, arguing that claims on the RTTC "mobilize people on the basis of propinquity and membership in a more legally ambiguous community than the nationstate." That is, vital urban citizenship and the distinctive civil societies it fosters may trump citizenship claims and identity formation at broader scales, generating a renewed "consciousness of the city and of urban reality" as dynamic spaces for political intervention (Lefebvre, 1996: 80). Inhabitants can, through claims on the right to the city, begin the work of changing the city by changing their perception of and relationship to it. This has profound potential for the creation and management of green space within urban environments.

Such a characterization of the transformative potential of RTTC framing belies the structural constraints on disrupting the dominant governance regime within cities, where exchange value supersedes use value to residents, and illuminates the need for a radical repositioning of power within urban systems. Harvey (2008: 38) acknowledges that urban governance, as currently constituted, is "restricted in most cases to a small political and economic elite who are in a position to shape cites more and more after their own desires." That average citizens lack the capacity to determine the structure, safety, and resources that constitute their built environment and public green space energizes and animates the cry and the demand of the Right to the City: the cry publicizes and announces an inherent injustice; the subsequent demand articulates and enacts a collective alternative vision.

While Lefebvre offers a vague sense of how a renewed and revitalized RTTC may enfranchise urban residents to work collaboratively in generating "city as oeuvre," he stops short of prescribing how such a transformation of power may actually occur. His primary interest, in The Right to the City, is to explore the historical processes that have contributed to contemporary urban formulations, and to suggest openings for challenging neoliberal capital's violent affront 
on cities and the people who call them home. The indeterminate character of Lefebvre's depiction of how the RTTC may actually transform urban space is, arguably, intentionally attentive to the scalar politics of urban inhabitance; struggles for the RTTC are inherently spatialized, and, as a result, there is no specific formula for universally enacting new forms of urban citizenship and claims on the RTTC.

I argue that there is a practical possibility of enacting a version of Lefebvre's vision of the RTTC at the sub-city or neighborhood scale, one that utilizes the emphases of UPE to focus on governance over urban nature. The transformation of public space by marginalized urban inhabitants of that space — enacting claims on the right to the city - may represent a democratization of the very processes by which cities take shape (Carrasco 2010), and thus a profound reorganization of existing social relations.

Systematic social reorganization does not rely on the participation by all residents of a particular city, and, in fact, that requirement would be untenable in most cases. While urban movements for the RTTC may "acknowledge and reinforce the city as a primary place of politics" (Samara, 2012: 45), they must simultaneously acknowledge and support the transformative potential of community- or neighborhood-based movements. While city-scale rights claims offer a public image of substantive change, organizations like the U.S.-based Right to the City Alliance (RTTCA) support movements which "operate only in part of the city; all are neighborhood- and community-based, not city-based" (Samara, 2012: 45). Because the neighborhood, not the city, is the "scale of everyday life" (Samara 2012: 45), it makes sense for rights claims to be made within that scale, but the "scaling down" of rights claims does not suggest those rights are provincial or ends unto themselves. As Nicholls and Vermeulen (2012) argue, the RTTC should be re-conceived as "rights through city;" the space of the city provides a 
political site for claiming rights that can then extend to larger scales. Referring to gay rights activism in the city of San Francisco, Nicholls and Vermeulen (2012: 81) point out, "the aim was not to gain rights to this one city and stop the struggle at the city gate, but to build on the relational and political advances made in this city to sustain the broader goal of gay rights in the country." Rights claims made at the scale of the neighborhood may also serve to "catalyze rights mobilizations" at the scale of the city and beyond, which is one reason neighborhood- and community-scale initiatives should be taken seriously for their transformative potential to generate a new "trickle-up" urban social politics.

As Purcell (2002) explains, the "nested scales" within which citizens operate complicate and often contradict their ability to affect changes to urban space and/or policy. Participation at the scale of the city is tightly linked to processes playing out at state, national, and supranational scales, which in most cases fall outside the purview of an individual or groups of citizens, and may counter localized progress or efforts toward systemic change. Mitchell (1997: 304) highlights the ways in which processes of globalization signal "the end of space" by "effectively masking the degree to which capital must be located" and permitting decision-makers at all scales "to argue that they have no choice but to prostrate themselves to the god Capital." While community-scale interventions may not interrupt the "annihilation of space" by globalized capital, they do offer "political moments" which can secure durable changes with the potential to "trickle up" spatial scales. Becher (2012: 203) defines political moments as “intentionally temporary, grassroots organizing around small-scale, specific claims.” Political moments are important, Becher argues, because they can secure durable changes for previously or historically disenfranchised urban residents, giving them "enduring control over their parts of the city in ways that other forms of politics may not make possible" (2012: 203). Political 
moments have three distinctive outcomes for engaged urban inhabitants, which arguably generate a new, neighborhood-scale RTTC: (1) They may mobilize people who don't consider themselves to be especially political; (2) They can develop inhabitants' personal commitments and abilities to access political power; and (3) they can change the function, purpose, or interest of local institutions to better meet residents' needs. Finally, to connect this framework to earlier discussions on UPE: neighborhood-scale claims on the right to the city must confront the multiscalar structural distributions of environmental goods and harms affecting residents if they are to be successful as socio-political or environmental projects.

In what follows I offer a portrait of a community-scale initiative in the Lower Ninth Ward neighborhood of New Orleans as an example of a political moment that has transformative potential for claims on the right to the city through governance over urban nature. To situate the work of the Lower Ninth Ward Food Access Coalition (LNWFAC), I introduce the Lower Ninth Ward neighborhood and the city of New Orleans in the wake of Hurricane Katrina, and position LNWFAC's demand for fresh food access within broader demands for self-determination and the right to the city.

\section{Findings: The Lower Ninth Ward Food Access Coalition}

The Lower Ninth Ward neighborhood of New Orleans had a pre-Katrina population 19,515 (US Census, 2000). Mostly African American and working class, $60 \%$ of neighborhood residents owned their own homes, and most had been in their families for generations. Prior to the storm, the neighborhood contained a diversity of locally-owned businesses, and backyard gardening was common in the decades before Katrina (Passidomo 2013).

The near-total destruction of the Lower Ninth Ward after the levee failures following hurricanes Katrina and Rita, and subsequent investment and charitable efforts by prominent 
celebrities like Brad Pitt, thrust the neighborhood into international purview. The levees protecting the Lower Ninth Ward breached in two places, sending a surge of water that lifted homes from their foundations and tossed cars and trees about like toys. The floodwaters reached twenty feet in the lowest lying parts of the neighborhood, and in some cases did not recede for over a month. The devastation of this part of the city is hard to overemphasize. $100 \%$ of the neighborhood was flooded, and even those residents whose homes were marginally habitable were not allowed to return until nearly two months after the storm. Return to the neighborhood has been slow and appears to have stagnated; the 2010 census counted 5,556 residents, just $28 \%$ of pre-Katrina levels (GNOCDC, 2012; Passidomo 2013).

Despite the prominent visibility of the destruction following the levee failures, the abandonment of the Lower Ninth Ward preceded the storm by several decades (Dyson 2006; Gabe et al 2005). Only elderly lifelong residents of the neighborhood can recall a time when it was dotted with butcher shops, bakeries, and corner stores selling fresh fruits and vegetables; when produce vendors would push carts through the neighborhood selling their wares; and when backyard gardens were a ubiquitous feature of life in this rural-feeling suburb separated from the historic French Quarter by a canal, a railroad, and a vast racial and class divide. While the grocery and food vendors had long disappeared, backyard fruit and vegetable gardens remained common throughout the neighborhood up until the devastation of 2005.

The slow and stagnating rate of return to the Lower Ninth Ward left significant physical and social gaps, and threatened to deteriorate any sense of community that was maintained and nursed back to life as some residents returned home. The appearance of a wild reclamation by nature of what was once vital urban space led a reporter for the New York Times to depict the neighborhood as a "Jungleland," rife with snakes, feral dogs and cats, abandoned cars and boats, 
and voracious vegetal overgrowth (Rich, 2012). Offended by this characterization of her neighborhood, LNW native and community organizer Jenga Mwendo penned a rebuttal to the NYT article, which was published in the magazine Ebony. In her essay, Mwendo fought back, stating:

The New York Times Magazine recently ran a story on my home, the Lower Ninth Ward of New Orleans, a place one of the most powerful newspapers in the world insensitively dubbed a "Jungleland." Contrary to the article, residents of this community are not reconciled to life in the wilderness and we don't live in an untamed mess of overgrowth or in a forgotten wasteland. We are not resigned to anything; we are fighting to revive our community...[W]hile writing about broken people, vacant lots and weeds may be sexy journalism, the community needs the outside world to understand how implicit and unconscious bias caused by a history of racism pummeled us." (Mwendo 2012).

At the time that Mwendo authored that essay, she was deeply engaged in efforts to transform those weedy and vacant lots, and to help revitalize her community in the process. Because of the prominent historical role of backyard gardens, Mwendo began by forming a coalition of backyard gardeners as an effort to reconnect community members and to help heal the neighborhood after the storm. Mwendo founded the Backyard Gardeners' Network (BGN) in 2009, with the mission to "sustain and strengthen the historically self-sufficient and deeplyrooted community of the Lower Ninth Ward of New Orleans" (www.backyardgardenersnetwork.org). The nonprofit works to fulfill this mission by "using our own food growing traditions as a platform to build community, revitalize the neighborhood, and preserve cultural heritage." The organization of the BGN was a response to Mwendo's observation that her neighborhood, post-Katrina, lacked space for gathering and strengthening community bonds. Rather than starting from the premise that urban agriculture was emancipatory in and of itself, Mwendo and her neighbors drew on a long history of gardening in the neighborhood before determining that urban agriculture would be an appropriate vehicle for connecting residents to one another and to common goals of self-determination, the promotion of 
healthy eating, and the enhancement of intergenerational nature-literacy.

BGN operates two urban garden sites in the Lower Ninth Ward. The Laurentine Ernst Community Garden is a space where residents maintain food garden plots. The Guerilla Garden also contains individual garden plots, but primarily exists as a community gathering space, and is the main site for BGN educational events. These activities, which include music, cooking demonstrations, gardening classes, and celebrations of African American cultural history are geared to people of all ages and consistently draw large crowds to gather in this urban oasis.

Connecting the urban agriculture work to broader struggles to increase fresh food access in the neighborhood, in 2012 Mwendo mobilized residents—many of whom had connected through events and activities at the Guerilla Garden — in an eight-month long collaborative process to draft a "food action plan" for the neighborhood. The group of community activists called themselves the Lower Ninth Ward Food Access Coalition (LNWFAC). While their process had practical aims and results, including the formal publication of the Lower Ninth Ward Food Action Plan in 2013, the LNWFAC also saw the planning process as a time to interrogate structural racism, to celebrate social capital, and to place the food access struggle within broader struggles for social and economic justice. Crucially, they saw governance over their garden space as integral to their inhabitance in their community, and for fostering a connection to the natural world. Central to the LNWFAC's efforts was an explicit understanding that neighborhood residents - those most deeply invested in the health and wellbeing of the community—should have legitimate governance over the "vacant" lots that now occupied so much neighborhood space. By converting some of those lots into productive community space for gardening and gathering, the residents of the Lower Ninth Ward have demonstrated the profound potential of local governance over public green space. 


\section{Discussion and Conclusions}

The decade since Hurricane Katrina and the levee failures witnessed a rush, followed by a slow tapering off, of outside interest and investment in the Lower Ninth Ward. Volunteers have assisted tremendously in the rebuilding of the neighborhood, but many residents have consistently expressed concern that sustained and eager outside assistance may generate a sense among neighborhood residents that they aren't capable of doing the work themselves. The vast majority of those volunteers that have come to the Lower Ninth Ward over the past decadesome for an afternoon, some for several months or more - are young and white (Fussell et al 2009). Because of efforts like Teach for America, so too are many of the area's schoolteachers. The mayor of this majority-black city, too, is white. Residents of the Lower Ninth Ward may rightly ask: when we look to people in positions of power, people who have the capacity to affect change in our neighborhood and in our community, who do we see that is representative of us? Because the residents are invested in the neighborhood—arguably more so than ever, since many faced significant obstacles in order to come back after Katrina-residents should, ultimately be the people to determine where, how and by what means the neighborhood continues to evolve and develop.

Scholars have questioned the ongoing impact of post-Katrina urban agriculture projects. Kato and colleagues found that, in the case of New Orleans, "urban gardening activities in marginalized communities still recovering from the social disruption of Hurricane Katrina need to be seen both as countering practices of neoliberal abandonment and disaster capitalism, and as attempts to reclaim space and identity" (Kato et al, 2013, p. 1845). Lefebvre's characterization of the RTTC — as a radical entitlement of urban inhabitants to produce space to meet their own needs - provides a productive theoretical base from which to launch an investigation of such 
attempts to reclaim space and identity through taming urban nature and converting it into productive social space. Additionally, efforts that claim that space for food production and the communal sharing of food often operate on the premise that the ability to access, consume, and even produce culturally-appropriate nutritious food is a basic right contained within what Nik Heynen has referred to as the "geography of survival" (Heynen 2010). According to Heynen, the geography of survival comprises both the "spaces of social reproduction essential to human survival" by the economically and socially marginalized, as well as the spaces in which grassroots activism engages corporeal concerns of sustenance and inhabitance.

The themes and rights claims central to the RTTC framework also characterize discourses and ideologies contained within an urban food system manifestation of UPE, which argues that individuals and communities should have the power to utilize vacant green space to access and create a food system that meets their basic nutritional and cultural needs. Furthermore, I argue that the spatially specific nature of demands for food and green space access among low-income inhabitants — which constrain urban space to walkable scales - may more appropriately be considered claims on the right to the neighborhood. Such claims are examples of "political moments" because of their topical and temporal specificity, but they also signal towards broader struggles for justice and equality, and may contribute to rights claims at the scale of the city and beyond.

A central theme of Lefebvre's characterization of the RTTC is that of inhabitance, the notion that urban residents do not just occupy physical space, but rather are socially and personally involved in the creation and use of that space. Members of the LNWFAC meet channel their inhabitance by reflecting on historic legacies of segregation and oppression that have contributed to multi-generational citizenship claims within the Lower Ninth Ward 
neighborhood, and identify themselves collectively as "a strong and proud Lower Ninth Ward community." As inhabitants concerned with the use value of their neighborhood, LNWFAC members join other LNW residents in opposing efforts to commodify their neighborhood in the wake of the destructions caused by Hurricanes Katrina and Rita. "Disaster tourism" is a lucrative business in the LNW, with around thirty companies offering bus tours of the "devastation that displaced hundreds of thousands of residents" (BigEasyTours.com; Gerdes 2012). Residents of the Lower Ninth Ward have resisted these efforts to cash in on their misery and cast their neighborhood as spectacle; as one resident told a reporter for the Associated Press, "We're fed up and tired of them coming through the neighborhood like we're some sideshow. After all the suffering we have been through, we deserve more respect than this." (Telegraph, Oct. 5, 2012). Mwendo's repudiation of the "Jungleland" characterization, and vocal protestations of other Lower Ninth Ward residents who prioritize their neighborhood affiliation and situate their rights claims within the space of the neighborhood, demonstrate the scalar politics of claims on the right to access and interact with urban nature. Food access is not a citywide problem in New Orleans; like other disinvested communities throughout the United States, "food deserts" cluster in low-income communities and tend not to characterize entire cities. Wealthier parts of New Orleans (where most residents own personal vehicles anyway) have seen remarkable rebuilding and have consistent and convenient access to fresh foods within easy walking distance. The mobilization of Lower Ninth Ward residents who lack sufficient access to fresh food was thus inherently neighborhood-based. Smith and McQuarrie's (2012: 3) argument that claims on the RTTC "mobilize people on the basis of propinquity and membership in a more legally ambiguous community than the nation-state" rings especially true at the scale of the neighborhood, which is the scale of everyday life, and the scale at which LNWFAC members 
feel capable of demanding and enacting changes to their lived urban landscape. Thus, citizenship claims by LNWFAC members also occur at the neighborhood scale. At meetings of the LNWFAC, residents introduced themselves as "born and bred in the Lower Ninth Ward" or "second [or third, or fourth] generation resident of the Lower Ninth Ward." By proclaiming the primacy of their role as Lower Ninth Ward residents to "decide what we want for our community," the LNWFAC exhibits radical urban inhabitance through claims on the right to their neighborhood.

The indeterminacy of Lefebvre's characterization of how the RTTC might be enacted suggests the need for articulations that are spatially and contextually specific. Insights from urban political ecology scholarship illuminate the embedded and potential political and governance regimes that underlie urban inhabitance and relations to socio-nature. The LNWFAC's focused demand for food that is "fresh, quality, convenient and affordable," their collaborative effort to transform the limited food options available in their community, and their use of public green space to enhance community solidarity, constitute a legitimate claim of the right to transform the urban (green) space in which they live. Their efforts are an example of the transformative potential of a "political moment" (Becher, 2012) which enacts substantive change through (1) mobilizing people who don't consider themselves to be especially political; (2) developing inhabitants' personal commitments and abilities to access power; (3) potentially changing the function, purpose, or interest of local institutions to better meet residents' needs. Members of the LNWFAC mobilized around a specific goal that they recognized as situated within a broader struggle for economic and racial justice. Their collaborative visioning and activism demonstrate the potential of neighborhood-scale political moments to spark participation and appropriation among historically marginalized groups. Because access to food 
and to community green space represent urgent individual and collective needs, localized and specific struggles open up productive spaces from which to launch broader campaigns claiming the right to the city; the LNWFAC's grassroots structure and neighborhood-scale organizing offer instructive examples of what the beginning of a renewed right to urban nature might look like. 


\section{$\underline{\text { Acknowledgements }}$}

This research was funded by grants from the National Science Foundation (DDRIG \#1129728) and the Graduate School at the University of Georgia. Appreciation goes out to Hilda Kurtz and Amy Trauger of the University of Georgia, Yuki Kato of Tulane University, and Jenga Mwendo for many fruitful discussions regarding this and other work. 


\section{$\underline{\text { References }}$}

Bakker, K. (2005) 'Katrina: the public transcript of 'disaster.' Environment and Planning D: Society and Space, 23:795-802.

Becher, Debbie (2012) "Political moments with long-term consequences," in Michael Peter Smith and Michael McQuarrie (Eds.), Remaking Urban Citizenship: Organizations, institutions, and the right to the city. New Brunswick, NJ: Transaction Publishers. Pp. 203-220.

Bentsen, P. A. C. Lindholst, and C.C. Konijnendijk (2010) Reviewing eight years of urban forestry and urban greening: taking stock, looking ahead. Urban Forestry and Urban Greening, 9: 273-280.

Bickerstaff, K., H. Bulkeley, and J. Painter (2009) "Justice, nature and the city." International Journal of Urban and Regional Research, 33 (3): 591-600.

Bullard, R.D. (1983) “Solid waste sites and the Houston black community.” Sociological Inquiry, 53 (2-3): 273-88.

Butler, Chris (2012) Henri Lefebvre: Spatial politics, everyday life and the right to the city. Abingdon, Oxon: Routledge.

Braun, B. (2005) "Environmental issues: Writing a more-than-human urban geography." Progress in Human Geography, 29 (5): 635-650

Carrasco, S. (2010) "The right to the city: Shaping the city that makes us." Revista Amauta, August 1. Available online: http://revista-amauta.org/2010/08/the-right-to-the-cityshaping-the-city-that-makes-us/.

de Souza, Marcelo Lopes (2012) "Panem et circenses versus right to the city (centre) in Rio de Janeiro: A short report.” City, 16 (5). 
“Disaster tourism angers New Orleans residents.” Telegraph. Oct. 5, 2012.

http://www.telegraph.co.uk/travel/travelnews/9589129/Disaster-tourism-angers-New-

Orleans-residents.html

Domene, E. and D. Sauri (2007) "Urbanization and class-produced natures: Vegetable gardens in the Barcelona Metropolitan Region.” Geoforum, 38: 287-298.

Dyson, Michael Eric (2006) Come Hell or High Water: Hurricane Katrina and the Color of Disaster. New York: Basic Books.

Fussell, Elizabeth, Narayan Sastry, Mark VanLandingham (2009) "Race, socioeconomic status, and return migration to New Orleans after Hurricane Katrina.” Population Studies Center, University of Michigan Institute for Social Research.

http://www.psc.isr.umich.edu/pubs/pdf/rr09-667.pdf

Gabe, T., Falk, G., M. McCarty and V.W. Mason (2005). “Hurricane Katrina: SocialDemographic Characteristics of Impacted Areas.” Congressional Research Service Report for Congress. Available online:

https://gnocdc.s3.amazonaws.com/reports/crsrept.pdf

Gerdes, Caroline (2012) "Seven years after the storm, Katrina tours cause controversy.” National Geographic Online. November 6.

http://newswatch.nationalgeographic.com/2012/11/06/seven-years-after-the-stormkatrina-tours-cause-controversy/

GNOCDC (Greater New Orleans Community Data Center) (2012). "Facts for Features:

Hurricane Katrina Impact.”

http://www.gnocdc.org/Factsforfeatures/HurricaneKatrinaImpact/index.html 
Guitart, Daniela, Catherine Pickering, and Jason Byrne (2012) Past results and future directions in urban community gardens research. Urban Forestry and Urban Greening. 11: 364-373

Haaland, Christine and Cecil Konijnendijk van Bosch (2015) Challenges and strategies for urban green-space planning in cities undergoing densification: A review. Urban Forestry and Urban Greening, 14" 760-771.

Hartman, Chester, and Gregory D. Squires, Eds. (2006) There's no such thing as a natural disaster: Race, class, and hurricane Katrina. New York: Routledge.

Harvey, David. (2008) "The right to the city." The New Left Review, 53: 23-51.

Harvey, Daina, Yuki Kato and Catarina Passidomo (2015) Rebuilding others' communities: A critical analysis of race and nativism in non-profits in the aftermath of Hurricane Katrina. Local Environment. Published online July 10.

Heynen, N. (2006a) "Justice of eating in the city: The political ecology of urban hunger." In N. Heynen, M. Kaika, and E. Swyngedouw (Eds.), In the Nature of Cities: Urban Political Ecology and the Politics of Urban Metabolism. London and New York: Routledge.

Heynen, N. (2006b) "The political ecology of uneven urban green space: The impact of political economy on race and ethnicity in producing environmental inequality in Milwaukee.” Urban Affairs Review, 42 (1): 3-25.

Heynen, N., H. Perkins, and P. Roy (2006) "The political ecology of uneven green space: The impact of political economy on race and ethnicity in producing environmental inequality in Milwaukee." Urban Affairs Review, 42 (1): 3-25.

Kattel, Giri, Hisham Elkadi and Helen Meikle (2013) Developing a complementary framework for urban ecology. Urban Forestry and Urban Greening, 12: 498-508. 
Klein, Naomi (2007) The Shock Doctrine: The rise of disaster capitalism. New York, NY: Picador.

Knabb, Richard D; Rhome, Jamie R.; Brown, Daniel P (2005). "Tropical Cyclone Report: Hurricane Katrina: 23-30 August 2005" (PDF). National Hurricane Center. Updated August 10, 2006.

Lawrence, Anna, Rik De Vreese, Mark Johnston, Cecil C.Konijnendijk van den Bosch, and Giovanni Sanesi (2013) Urban forest governance: Towards a framework for comparing approaches. Urban Forestry and Urban Greening, 12: 464-473.

Lefebvre, Henri (1991 [1974]) The production of space, trans. D. Nicholson-Smith. Oxford: Blackwell.

Lefebvre, Henri (1996) Writings on cities, trans. E. Kolfman and E. Lebas. Malden, MA: Blackwell.

Leontidou, L. (2010) 'Urban social movements in 'weak' civil societies: The right to the city and cosmopolitan activism in southern Europe." Urban Studies, 47 (6): 1179-1203.

Lower Ninth Ward Food Action Plan (2013). Consulted 7 March 2013 at http://www.sustainthenine.org/sites/default/files/uploadeddocuments/L9W\%20CSED\%20Food\%20Action\%20Plan\%20FINAL_sm_0.pdf

Luft, Rachel E. (2008) “Looking for common ground: Relief work in Post-Katrina New Orleans as an American parable of race and gender violence." Feminist Formations, 20 (3): 5-31.

"Many areas marked for green space after Hurricane Katrina have rebounded." The TimesPicayune. August 23, 2010. http://www.nola.com/katrina/index.ssf/2010/08/many_areas_marked_for_green_space_af ter_hurricane_katrina_have_rebounded.html 
McClintock, Nathan (2010) Why farm the city? Theorizing urban agriculture through the lens of metabolic rift. Cambridge Journal of Regions, Economy and Society, 3: 191-207

McLain, Rebecca, Melissa Poe, Patrick T. Hurley, Joyce Lecompte-Mastenbrook, Marla R. Emery (2012) Producing edible landscapes in Seattle's urban forest. Urban Forestry and Urban Greening, 11: 187-194.

Mitchell, Don (1997) "The annihilation of space by law: The roots and implications of antihomelessness laws in the United States." Antipode, 29 (3): 303-335.

Mitchell, Don (2003) Right to the City: Social Justice and the Fight for Public Space. New York City: Guilford Press.

Mwendo, Jenga (2012) “Jungleland? New Orleans community activist rejects NY Times depiction of $9^{\text {th }}$ Ward." Ebony, May 9. http://www.ebony.com/news-views/junglelandnew-orleans-community-activist-rejects-ny-times-depiction-of-9th-ward

Nicholls, Walter and Floris Vermeulen (2012) "Rights through city: The urban basis of immigrant rights struggles in Amsterdam and Paris," in Michael Peter Smith and Michael McQuarrie (Eds.), Remaking Urban Citizenship: Organizations, institutions, and the right to the city. New Brunswick, NJ: Transaction Publishers. Pp. 79-97.

NOAA (The National Oceanic and Atmospheric Administration) (2011) "The deadliest, costliest and most intense United States tropical cyclones from 1851 to 2010 (and other frequently requested hurricane facts)". National Climatic Data Center, National Hurricane Center. National Oceanic and Atmospheric Administration, p. 47.

Passidomo, Catarina (2013) "Whose right to (farm) the city? Race and food justice activism in post-Katrina New Orleans." Agriculture and Human Values, 31 (3): 385-396. 
Parnell, S. and E. Pieterse (2010) “The 'right to the city': Institutional imperatives of a developmental state." International Journal of Urban and Regional Research, 34 (1): 146-162.

"Plan shrinks city footprint." The Times-Picayune. December 14, 2005. http://www.nola.com/politics/index.ssf/2005/12/plan_shrinks_city_footprint.html

Purcell, M. (2002) "Excavating Lefebvre: The right to the city and its urban politics of the inhabitant." Geojournal, 58: 99-108.

Purcell, M. (2003) "Citizenship and the right to the global city: Reimagining the capitalist world order." International Journal of Urban and Rural Research, 27 (3): 564-590.

Rich, Nathaniel (2012) “Jungleland.” New York Times Magazine, March 21. http://www.nytimes.com/2012/03/25/magazine/the-lower-ninth-ward-new-orleans.html Samara, Tony Roshan (2012) "Citizens in search of a city: Towards a new infrastructure of political belonging," in Michael Peter Smith and Michael McQuarrie (Eds.), Remaking Urban Citizenship: Organizations, institutions, and the right to the city. New Brunswick, NJ: Transaction Publishers. Pp. 39-56.

Smith, Michael Peter and Michael McQuarrie (2012) Remaking Urban Citizenship: Organizations, institutions, and the right to the city. New Brunswick, NJ: Transaction Publishers.

Swyngedouw, E. and N. Heynen (2003) Urban political ecology, justice, and the politics of scale. Antipode, 35 (5): 898-918.

Trauger, Amy and Catarina Passidomo (2012) Towards a post-capitalist politics of food: Cultivating subjects of community economies. Acme, 11 (2): 282-303. 